EUROPEAN ASSOCIATION

FOR THE STUDY OF DIABETES
ASSOCIATION EUROPÉENNE

POUR L'ÉTUDE

DU DIABETE
EUROPÄISCHE

GESELLSCHAFT FÜR

DIABETOLOGIE

\title{
ORGANIZATION SECTION
}

President:

A. E. Renold, Geneva (retires 1977)

Vice-Presidents: J: Mirouze, Montpellier (retires 1978)

S. Sailer, Innsbruck (retires 1978)

Past President: W. Creutzfeldt, Göttingen

Hon. Secretary: P. J. Lefebvre, Liege (retires 1979)

Hon. Treasurer: T.D.R. Hockaday, Oxford (retires 1978)

\section{DIABETOLOGIA:}

Editor-in-Chief:

K. G. M. M. Alberti, Southampton (1977-1980)

Executive Director: Mr. James G. L. Jackson, 3/6 Alfred Place, London WC1E 7EE, England

\section{COUNCIL}

Term expiring 1977

R. Assan, Paris

H. Frerichs, Göttingen

J. Schlichtkrull, Bagsvaerd

E. Shafrir, Jerusalem
Term expiring 1978

L. Adezati, Genoa

D. C. Andreev, Sofia

A. Labhart, Zurich
Term expiring 1979

T. Deckert, Gentofte

C. N. Hales, Cardiff

J. J. Hoet, Louvain

A. Rigas, Athens

J. Taton, Warsaw

HONORARY MEMBERS

C. H. Best, Toronto - M. Derot, Paris - R. Levine, Duarte - K. Oberdisse, Düsseldorf - Sir Frank Young, Cambridge

\section{SUPPORTING AND ASSOCIATE MEMBERS}

Ames Europe, Slough - Bayer AG, Leverkusen - Boehringer, Mannheim - British Insulin Manufacturers, United Kingdom - Hoechst AG, Frankfurt - Hormon-Chemie, Munich - Novo Foundation, Bagsvaerd - Pfizer AG, Zurich - Sandoz AG, Basel - Laboratoires Servier, Neuilly - Schering AG, Berlin - Upjohn Company, Kalamazoo - Winthrop Laboratories, Surbiton.

FUTURE MEETINGS

28-30 September, 1977: Geneva, Switzerland

28-30 September, 1978: Zagreb, Yugoslavia

\section{Minutes of 12th General Assembly of the European Association for the Study of Diabetes, Held in Finlandia Hall, Helsinki, Finland, on Thursday, 2nd September, 1976 at 10.30}

Present: Dr. A. E. Renold (President)

Dr. B. Hellman (Hon. Secretary)

Dr. T. D. R. Hockaday (Hon. Treasurer)

Dr. W. Creutzfeldt (Editor-in-Chief, Diabetologia)

and 217 members of the Association.

In his opening remarks, the President expressed the warm thanks of the Association to Dr.E. A. Nikkila and Dr. R. Pelkonen for the excellent arrangements which they had made for the 12th Annual Meeting of the Association, and added his thanks to the Finnish people for providing Finlandia Hall.

\section{Minutes, 11th General Assembly}

The Minutes of the 11th General Assembly, held in Munich, having been printed in Diabetologia, Vol. 12,2, 1976, were taken as read and confirmed as a correct record. The file copy was signed by the President and Honorary Secretary.

\section{Reports}

a) President

Dr. Renold commented on the remarkable success of the 11 th Annual Meeting in Munich, both scientifically and financially. This had eased the otherwise serious financial position of the Association, and the President expressed the Association's grateful thanks to Dr. H. Mehnert and his Organising Committee for their efficient administration.

Continuing, the President reported that the Minkowski Award Committee had unanimously selected Dr. K.D. Hepp as the 1976 recipient of the Minkowski Prize. He expressed the Association's thanks to Farbwerke Hoechst for their continued sponsorship of this much valued Prize. Dr. Renold also paid tribute to the Paul Neumann Laboratories for their generous sponsorship of the Claude Bernard Lectureship, which was to be given by Dr. H.G. Hers at the close of the current meeting. The President reported that Dr. D. L. Coleman, of Bar Harbor, USA was to be invited to give the 1977 Claude Bernard Lecture in Geneva.

The President then paid tribute to the valued and vital support of the supporting pharmaceutical Members, and especially to Novo Industri for their renewed annual grant for Travel Awards and their generous subvention for the production of the Volume of Abstracts.

With regret, Dr. Renold reported that the Pfizer-Europe Company was unable to renew its valued grant for Travel Fellowships which it had so generously sponsored over the past six years. As a result of these Fellowships, exchange visits between laboratories in Europe and the United States had been made possible for 16 individuals, and they had fulfilled an important role. Hopefully, through support from another company, the Association would be able to renew this kind of Fellowship in the future. 
To warm applause, the President paid tribute to Dr.E.A. Nikkila who retired as a Vice-President by rotation; and also to Dr. B. Hellman, who similarly retired from his office of Honorary Secretary after a period of three years. The President expressed his warm thanks for their dedication and efficièncy, and emphasised the indebtedness of the Association to Dr. Hellman in his capacity of Chairman and Convenor of the Programme Committee, whose careful selection of papers had helped to make the meetings so successful. He was confident that the high standards set would be maintained by the new Honorary Secretary, Dr. Pierre Lefebvre.

Finally, Dr. Renold referred to the retirement by rotation of the Joint Editors-in-Chief of Diabetologia, whose term of office would cease at the end of 1976. The Association owed a deep debt of gratitude to Drs. W. Creutzfeldt and K. Schoffling for their faithful and effective service throughout the past four years. To succeed them, the Council had appointed Dr. K. G. M. M. Alberti, of Southampton, and the President wished Dr. Alberti an equally happy and successful period of office starting on 1st January, 1977.

In conclusion, the President thanked all members of the Association for their continued support of the aims and objects of the Association.

\section{b) Honorary Treasurer}

Dr.T.D.R. Hockaday presented the accounts: Consolidated $A c$ counts Using Conversion Rate of $£ 1=S F r .5 .35$ Income and Expenditure Account for the year ended 31st December, 1975
1974

$£$

Income

Subscriptions:

1739 Active Members

1975

3563

Supporting and Associate Members 4065.52

5302

122 General Donations

6621.95

127.97

785 Bank Interest

287.66

$£ 6209$

Expenditure

Secretariat Expenses:

1905 Salaries

660 Rent, Heat \& Light $\quad 700.00$

508 Post, Phone, Travel etc. $\quad 832.08$

50 Audit Fee $\quad 100.00$

- Membership List $\quad 337.50$

3123
436 Executive Committee Meeting Expenses 4084.56

646.18

11th Annual Meeting Expenses $\quad 3192.93$

Less: Transfer from Surplus $\quad 2258.54$

2456

2445 Diabetologia Secretarial Expenses

9 Bank Charges

8469

2260 Less: Deficit for year

$£ 6209$

934.39

2575.06

11.48

8251.67

1214.09

f. 7037.58
Balance Sheet as at 31st December, 1975

Income \& Expenditure Account

9250 Balance at 1st January, 1975

112 Exchange Equalisation Account
- Transfer from Annnual Meetings Fund

\begin{tabular}{|c|c|c|}
\hline \multicolumn{3}{|c|}{2500.00} \\
\hline 6862 & & 5259.12 \\
\hline 2260 & Deficit for year & \\
\hline 2759 & & 4045.03 \\
\hline 3766 & Pfizer-Europe Travel Fellowships Fund & 5820.46 \\
\hline 2090 & EASD Travel Fund & 6481.03 \\
\hline 548 & Annual Meetings Fund & 2505.88 \\
\hline 2319 & Membership and Journal Subscriptions & 7500.28 \\
\hline$£ 11482$ & & $£ 26352.68$ \\
\hline
\end{tabular}

Commenting on the financial problems of the Association, the Honorary Treasurer pointed out that whereas in 1973 there had been a surplus, both in 1974 and 1975 there had been a deficit. To some extent the accounts were misleading since the continued fall in the value of the pound sterling meant that the exchange rate had changed from SFr. 6.00 in 1974 to SFr. 5.35 in 1975, and the current rate was SFr. 4.40. So long as money was spent in the United Kingdom this fall was in the Association's favour, but as soon as money had to be spent abroad, the Association suffered.

Income in 1975 had risen slightly, but so also had expenditure. However, thanks to the surplus achieved on the Munich meeting, the increase in expenditure had been kept within reasonable proportions. The Munich surplus of $£ 11,000$ had been allocated between the Secretariat meeting expenses, the EASD Travel Fund and had also been used to repay to the General Funds the special grant of $£ 2,500$ which had been transferred to meet the higher cost of travel grants in 1973. $f 4,500$ had been transferred to the EASD Travel Fund to enable the Association to give an increased number of grants for the current, and future, meetings.

Thus the Association ended the year with assets of $£ 26,000$ compared with $£ 11,000$ in 1974 . However, Dr. Hockaday drew attention to the increasing cost of administration, and warned the membership of a possible increase in annual subscription rates, unless a considerably larger number of individuals could be encouraged to join. He concluded his report by quoting the last words of Wilfred Owen: "Without some money, nothing is possible".

The President thanked Dr. Hockaday for his report.

c) Honorary Secretary

Presenting his report, Dr. Hellman said that 122 new members had been admitted to the Association in the past year, an increase of 12 over 1974; but there had been an increase in the number of "lapsed" members and deaths and resignations. The break-down of the membership was as follows:

$\begin{array}{lrlr}\text { Argentina } & 1 & \text { Italy } & 74 \\ \text { Australia } & 8 & \text { Japan } & 6 \\ \text { Austria } & 16 & \text { Lebanon } & 2 \\ \text { Belgium } & 55 & \text { Luxembourg } & 2 \\ \text { Bulgaria } & 6 & \text { Morocco } & - \\ \text { Canada } & 5 & \text { Netherlands } & 28 \\ \text { Chile } & 1 & \text { New Zealand } & 3 \\ \text { Cuba } & 1 & \text { Norway } & 8 \\ \text { CSSR } & 22 & \text { Poland } & 12 \\ \text { Denmark } & 51 & \text { Portugal } & 9 \\ \text { Dominican Rep } & 1 & \text { Romania } & 20 \\ \text { Egypt } & 2 & \text { Russia } & - \\ \text { Finland } & 11 & \text { S. Africa } & 4 \\ \text { France } & 93 & \text { Spain } & 28 \\ \text { Germany, East (DDR) } & 23 & \text { Sweden } & 44 \\ \text { Germany, West (FRG) } & 103 & \text { Switzerland } & 65 \\ \text { Greece } & 12 & \text { Turkey } & 7 \\ \text { Hungary } & 23 & \text { UK, Ireland } & 142 \\ \text { India } & 2 & \text { USA } & 28 \\ \text { Iraq } & 1 & \text { Uruguay } & 1 \\ \text { Israel } & 26 & \text { Yugoslavia } & 14 \\ & 463 & & 960\end{array}$


Only 37 members had been supported through Travel Grants in 1975, but thanks to the success of the Munich meeting, Travel Grants had been offered to 55 members for the current meeting. Dr. Hellman emphasised that Travel Grants were only made to persons who are paid-up members of the Association. Over the past eight years, 284 grants had been awarded.

The final Pfizer-Europe Travel Fellowships had been awarded to Drs. C. E. Upton (UK), D.H. Mintz (USA), J.C. Hutton (Australia), V. A. Koivisto (Finland) and J.H. Thomas (UK).

Nine nominations had been received for the 1976 Minkowski Prize. These nominations were now sent to the Secretariat in London.

The dates of future meetings were as follows:

1977: 28-30 September: Geneva, Switzerland

1978: 28-30 September: Zagreb, Yugoslavia

Until the venue of the 10th IDF Congress was known, no decision could be taken about an EASD meeting in 1979, but if the IDF met in Europe, there would be no EASD scientific meeting.

This being his last report as Honorary Secretary, Dr. Hellman wished to thank the Association for the privilege of being able to serve his fellow members. He thanked the Officers and members of the Council, and in particular the Executive Director, for all their help, and hoped that Dr. Lefebvre would have as happy a term of office as his had been.

The President thanked Dr. Hellman for his report.

e) Editor-in-Chief, Diabetologia

On behalf of his co-Editor, Dr. K. Schoffling, Dr. W. Creutzfeldt presented the report.

The Joint Editor-in-Chief first drew attention to the fall in the number of subscribers to the Journal over the past year. The main losses had been from Belgium, France, West Germany and Italy, and whilst these had been offset to some extent by increases from Japan, Australia, United Kingdom and the United States of America, the total number of subscribers had fallen by 14 to 1,463 . Unfortunately, there were increasingly few private subscribers, and Dr. Creutzfeldt pointed out that only 90 members of the EASD took advantage of the generous preferential discount of $33 \frac{1}{1} \%$ which was available to members.

The number of manuscripts received in 1975 was 159 , compared with 145 in 1974 . Of these, $49.1 \%$ had been accepted for publication. The United Kingdom and the United States of America submitted the highest number of manuscripts, but those from the United States suffered the highest rate of rejection. Already, 120 papers had been submitted for 1976 , and if this trend continued the total number of manuscripts would again increase. If the rejection rate was not to rise, the Editorial Board might have to consider increasing the number of pages, and thus the annual subscription rate: or seek financial support from the Association or from Supporting Members. Attempts were made to shorten submitted manuscripts as much as possible.

Dr. Creutzfeldt then paid tribute to the work of the reviewers and pointed out that $41.4 \%$ of the reviews requested had been returned within three weeks. Only $1.2 \%$ of the papers sent for review had not been returned at all.

The total publication time had been reduced to 8.6 months, compared with 8.8 months in 1974. Half of this time interval was needed for publication procedures after a manuscript was accepted. The average time from "received" to "rejected" was 2.1 months. The average time of 4.3 months required for the final acceptance of a paper included the time taken by authors to revise their manuscripts. 14 authors had required more than 6 months (and in one case 16 months) for revision, and this adversely affected the average time.

Since 1970 , the number of submitted manuscripts had doubled, whilst the rejection rate had changed from $20 \%$ in 1970 to $51 \%$ in 1975 .

One consequence of the change to offset printing was an apparent increase in the length of submitted manuscripts, but this was misleading since offset printing gave a $10 \%$ less page coverage.

86 papers had been published in 1975 , compared with 80 in 1974. In the first five issues of 1976,63 papers would be published in addition to three review papers which were the Minkowski, Claude Bernard and Joslin Memorial Lectures delivered during the Munich meeting.

Dr. Creutzfeldt paid tribute to the continued support of Novo Industri $\mathrm{A} / \mathrm{S}$ for their valued assistance in the publication of the Abstracts.

Finally, the Joint Editor-in-Chief pointed out that he and Dr.K. Schoffling retired at the end of the year. All manuscripts arriving up to 30th September would be handled by the Gottingen Editorial office. From 1st October, 1976, manuscripts should be sent direct to the new Editor-in-Chief of the Journal.

On behalf of Dr. Schoffling and himself, Dr. Creutzfeldt wished to thank all members of the Editorial and Advisory Boards for their valued help over the past four years, as well as the many worldwide referees and the members of the Council. To the new Editor-in-Chief of Diabetologia he wished every support and help and expressed the hope that the journal of the Association would continue to be attractive to authors and readers of the international community of diabetologists.

The President expressed to Dr. Creutzfeldt and, in absentia, to Dr. Schoffling warm thanks for the devoted service given to Diabetologia over the past four years.

\section{Elections}

a) Council Members 1977-1980

For the benefit of newer members, the President reviewed the procedure by which members were elected to the Council. Five members retire each year by rotation, and are not eligible for immediate re-election, with the exception of a President-Elect. The Executive Committee, at their annual meetings consider nominations which are then submitted to the Council for their approval or amendment before being placed before the General Assembly for their final decision. For the sake of efficient administration nominations were made one year in advance, to take office at the next following General Assembly. Every effort was made to ensure a balanced representation throughout Europe.

The President then put forward the nominations agreed by the Council, to take office after the General Assembly in Geneva, 1977, and in place of those who would be retiring in that year, namely: Drs. F.M. Gerritzen, J. Pirart, K. Seige, M. SerranoRios, W. Creutzfeldt and K. Schoffling.

The General Assembly approved the election of the following:

\author{
Dr.P. R. Bouman (Netherlands) \\ Dr. P. E. Lisboa (Portugal) \\ Dr.P.J. Randle (UK) \\ Dr. J. Tamarit (Spain) \\ Dr. K. F. Weinges (FRG)
}

The General Assembly having approved these nominations, the President was happy to announce that the Council had unanimously approved the appointment of Dr. P.J. Randle (UK) as President of the Association for the period 1977-1980.

Dr. Renold also announced that the Council had appointed Dr.S. Sailer (Austria) as Vice-President in succession to Dr.E. A. Nikkila, for the period 1976-1978.

\section{b) Honorary Auditors, 1976-1977}

The General Assembly approved the election of Drs. G. Pozza (Italy) and K. D. Hepp (FRG) as Honorary Auditors for the ensuing year.

\section{Study Groups}

\section{a) Pregnancy}

Dr.J.J. Hoet reported that the sixth meeting of the Diabetic Pregnancy Study Group had been held in Vienna, and the next 
meeting was to be held in Ulm on 22-25 September, 1976. The Group had been invited to organise a half-day session on Diabetes and Pregnancy during the fifth European Meeting of Perinatal Medicine in Uppsala, which was attended by 2,000 participants.

The activities of the group had been made possible thanks to special grants from the Wellcome Foundation, Novo Industri and Ames Company.

b) Epidemiology

Dr. V. Schliack reported that the 1976 meeting of the Epidemiology Study Group had been held in Bulgaria, and had been organised by Dr. D. C. Andreev. The costs had been covered by the Bulgarian government. The 1977 meeting would be held in Copenhagen, and organised by Drs. T. Deckert and C. Binder.

A summary of the report would appear in the IDF Bulletin, Vol. XXI, 3, 1976.

\section{c) Postgraduate Education}

Dr. J. J. Hoet reported on the activities of the Postgraduate Education Group. A five-day course had been held in Southampton University, of which Dr. Alberti had been the convenor. From June 13 to 18, 1977, a course would be organised in Potsdam, DDR, which would be conducted in German: Dr. Schliack was convenor of this meeting. An additional postgraduate course would be held in Italy in October, 1977, for which Dr. Dr. Andreani was the convenor.
The sub-committee wished to thank the Council for their administrative facilities in the realisation of the group's aims.

The President said that the three study groups seemed to be very successful additional activities of the Association, and helped to further contact with other groups. He expressed his thanks to those who were using their work in this specialised way.

\section{Any Other Business}

The President reported that the Council had considered letters received from two members concerning the submission of $\mathrm{Ab}$ stracts. The Council therefore recommended that in future no presenting author would be permitted to submit more than one Abstract. The Council had expressed the hope that groups would refrain from including the same author on more than two $\mathrm{Ab}$ stracts, without making this mandatory.

Dr. Pirart urged that the slides of conclusions should remain on display throughout the discussion period. The President stated that authors had been asked to follow this practice, but it was difficult to enforce.

In his closing remarks the President wished to thank the Executive Director and the retiring members of the Council for their valuable service.

There being no other business to discuss, the President declared the meeting closed.

\section{3th Midwest Conference on Endocrinology and Metabolism „The Endocrine Pancreas and Juvenile Diabetes“}

The conference in honor of Dr. R. L.Jackson will take place at the University of Missouri, Columbia, 28-30 September,1977. Contributors include Dr. R. Levine, Dr. A. Rubinstein, Dr. C. R. Park, Dr. M. Sperling, Dr. J. Gerich, Dr. R. S. Bar, Dr. R. S. Clements, Dr. J. Williamson, Dr. R. Spiro, Dr. M.W. Steffes and Dr. B. R. Boshell. For further information contact: Professor R. R. Anderson, University of MissouriColumbia, 103 Eckles Hall, Columbia, Missouri 65201, U.S.A.

\section{Society for Endocrinology, Metabolism and Diabetes of Southern Africa}

An Endocrine - Gastroenterology Conference will be held from 5th - 7th December 1977 in Cape Town. Topics include: General aspects of endocrinology - Hormones of the gut and brain - General aspects of gastroenterology. Several prominent international guest speakers will participate. Registration fee, R 20,00 for physicians (R 10,00 for residents and research workers), which includes lunches. Further information from the Secretary (Dr. B.I. Joffe), Society for Endocrinology, Metabolism and Diabetes of Southern Africa, Department of Medicine, University of the Witwatersrand Medical School, Esselen Street, Johannesburg 2001; or the Secretary (Dr. M. Moshal), Society of Gastroenterology, Department of Gastroenterology, University of Natal Medical School, Durban 4013.

\section{5th International Meeting of Endocrinology}

The 5th International Meeting of Endocrinology „,Diabetes and Obesity“ will take place at Marseille, 8-11 June 1978. The meeting will deal with various aspects of obesity, including presentations by Drs. M. Apfelbaum, F. Bonnet, P. Freychet, S. Fajans, J. Koebberling, H. Keen, J. Vague, J. L. Codaccioni, A. E. Renold, P. Felig, G. Reaven, Ph. Vague, P. Bastenie, R. Levine, J. P. Felber, J. Pirart, J. Mirouze, G. Debry, B. Guy-Grand, E. Nikkilä, A. Jouve, and E. Pfeiffer. Those interested in presenting free communications should send an abstract in triplicate, maximum 200 words, by February 1st 1978. Further information may be obtained from Dr. PhilippeVague, Secrétaire Général, Clinique Endocrinologique, C. H. U. de la Timone, F-13385 Marseille Cedex 4, France.

Responsible for the text: Prof. K. G. M.M. Alberti, Chemical Pathology and Human Metabolism, Level D, South Laboratory and Pathology Block, General Hospital, Southampton S09 4XY, England

Responsible for advertisements: L. Siegel, G. Martin, Kurfürstendamm 237, D-1000 Berlin 15, Springer-Verlag Berlin-Heidelberg-New York, Printed in Germany by aprinta, Wemding

Copyright @ by Springer-Verlag Berlin-Heidelberg 1977 